\title{
Resenha
}

\section{PASSINI, Elza Yasuko. Prática de ensino de Geografia e estágio supervisionado. São Paulo: Contexto, 2007. 221p.}

\author{
Valney Dias Rigonato - UEG - Anapólis - Brasil \\ valney_rigonato@yahoo.com.br
}

Elas Yasuko Passini

Prática de ensino de geografia e estágio supervisionado

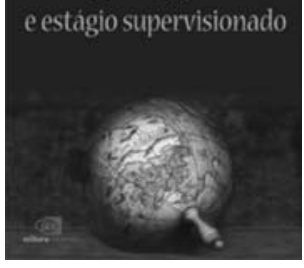

O livro retrata experiências oriundas da disciplina prática de ensino e estágio supervisionado de ensino de Geografia, desenvolvido na Universidade Estadual de Maringá-PR. A consolidação baseou-se na concepção de pesquisa colaborativa, na qual procura inter-relacionar a universidade e a escola no processo de formação inicial para os estagiários e formação continuada para os professores regentes.

A obra é composta de dezenove tópicos e anexos, os quais foram elaborados tanto pelos educandos como pelos professores responsáveis pelas disciplinas.

Fato este que demonstra a inovação no ensino-aprendizagem de professores de Geografia. Observa-se, também, um esforço na superação da lógica tradicionalista no ensino-aprendizagem e, consequentemente, para constituir uma nova práxis que possa propiciar a atuação crítica reflexiva da "teóriaprática-teória”.

Outro fator que revela a procura de superação pode ser evidenciado por algumas abordagens, tais como: parceria universidade-educação básica, novo professor, conhecimento moral, didática da afetividade, utilização de situações-problema, sala-ambiente, alfabetização cartográfica, multimídia, "cibersociedade" e auto-avaliação.

No entanto, percebe-se nas diversas temáticas construídas pelos autores uma auto-valorização do papel do professor diante dos diversos desafios do ensino público e privado neste princípio do século XXI. Diante disso, transforma-se o papel das práticas e do estágio supervisionado na consolidação de um novo professor, em especial, de Geografia. Entretanto, observase uma certa despolitização das relações entre "teória-prática-teória” a qual pode impossibilitar a compreensão do significado das políticas públicas no ensino básico e superior. 
O livro "Prática de ensino de Geografia e estágio supervisionado" é o retrato de um novo modelo de formação institucional de professores constituído após a promulgação da Lei no 9.394/96. O mesmo revela novas possibilidades didática e pedagógica de ensino-apredizagem de Geografia na formação de professores a partir da aproximação universidade-escola. Além disso, se bem compreendido, pode contribuir para a transformação de algumas práticas tradicionais do ensino de Geografia no espaço escolar.

A Geografia, uma disciplina outrora simplória e enfadonha, estaria sendo superada pelas novas práticas de ensino? Ou, ainda encontra-se amordaçada pelos construtos políticos dos Estados-Maiores, pelo interesse das grandes corporações comerciais e, portanto, (a)política diante das diversas territorialidades da chamada "sociedade em rede"? Qual o papel das disciplinas de práticas de ensino e de estágio supervisionado diante dessas questões?

Em síntese, o livro é um convite aos professores universitários e do ensino básico e, mormente, para os futuros educandos de licenciatura em Geografia. A obra viabiliza-nos represar o modelo de ensino-aprendizagem nas escolas e nas universidades, bem como, pode incentivar os grupos de pesquisas que acreditam na possibilidade de ensinar e desenvolver pesquisa-ação.

Valney Dias Rigonato - Mestre em Geografia, professor da Universidade Estadual de Goiás (UEG) e do Centro de Ensino e Pesquisa Aplicada à Educação (Colégio Aplicação). 